\title{
Kidney Cancer pT3c TNM Finding v6
}

National Cancer Institute

\section{Source}

National Cancer Institute. Kidney Cancer pT3c TNM Finding v6. NCI Thesaurus. Code C63569.

Kidney cancer with tumor grossly extending into the vena cava above the diaphragm, or invading the wall of the vena cava. (from AJCC 6th Ed.) 